\title{
PERENCANAAN DAN PENGENDALIAN KAPASITAS PRODUKSI PRODUK RAKITAN RADIO TIPE SOUNESS SNI 4250
}

\author{
A. Rahim Matondang ${ }^{1}$, Widodo ${ }^{2}$ \\ Dosen Departemen Teknik Industri ${ }^{1}$, Mahasiswa Departemen Teknik Industri ${ }^{2}$ \\ Fakultas Teknik, Universitas Sumatera Utara \\ Jl. Almamater, Medan 20155 \\ Kampus Padang Bulan, Medan \\ Email: widodoson@gmail.com
}

\begin{abstract}
Abstrak. Production system take an important role in industries, especially in manufacturing industries. This role determine the keys of successful company. Production process is an activity which produce finished product from raw material that involve machine, energy, and technique knowledge. Production process is real activity and can be seen by human being. The problems those always be faced in indutries management's are the arrangement of production schedule, such lack of inventory or overstock once the settlement of production process isn't on time. Production planning and control is activity to determine what product that will be produced, how many product that will be produced and how many labors needed in production processes. By using production planning and control's method, those problems can be minimalized. Aggregate planning is one of production planning a.nd control's method. By using this method, production planning could be done by using unit of replacement product so that the output of this planning isn't declared in individual product. So, the output of aggregate planning isn't planning in form of individual product but aggregate's product. There are some strategies on aggregate planning such as pure strategy on aggregate planning and mixed strategy on aggregate planning. In this research, method of aggregate planning that used is optimization approach by linier rule. This method used to make long term planning and middle term planning. Long term planning consists of product forecasting and aggregate planning. The middle term planning consist of master production schedule and rough cut capacity planning. The result of this research is capacity needed and capacity available to determine which work center is drum and which isn't. Conclusion of this research that capacity of each work center in perioad january to december 2018 is non drum. This indicate the good scheduling in capacity planning.
\end{abstract}

Keyword: Production Planning and Control, Aggregate Planning, Capacity Planning, Rough Cut Capacity 


\section{Pendahuluan}

Proses produksi adalah aktifitas dimana membuat produk jadi dari bahan baku yang melibatkan mesin, energi, dan pengetahuan teknis. Proses produksi merupakan tindakan nyata dan dapat dilihat. Masalah yang sering dihadapi oleh manajemen dalam menyusun rencana produksi, salah satunya yaitu kekurangan persediaan atau persediaan produk yang terlalu besar (overstock) serta penyelesaian proses produksi yang tidak tepat waktu.

Perencanaan dan pengendalian produksi adalah kegiatan yang berkenaan dengan penentuan apa yang harus diproduksi, berapa banyak diproduksi dan sumber daya apa yang dibutuhkan untuk mendapatkan produk yang telah ditetapkan.

Tujuan perencanaan produksi adalah sebagai langkah awal untuk menentukan aktivitas produksi, yaitu sebagai referensi perencanaan lebih rinci dari rencana agregat menjadi item dalam jadwal induk produksi.

Perusahaan manufaktur yang memproduksi plastik polyethylene tidak mampu memenuhi permintaan konsumen. Penelitian ini bertujuan untuk menentukan pusat kerja yang mengalami kekurangan kapasitas produksi dan kapasitas perencanaan produksi yang diusulkan sebagai pusat kerja alternatif untuk mengoptimalkan kapasitas produk dengan biaya minimal menggunakan metode Rough Cut Capacity Planning (RCCP) (Sarjono, 2016).

Masalah keputusan yang bersifat deterministic mixed integer sering digunakan untuk perencanaan jangka panjang, tetapi sistem produk yang real menghadapi serangkaian pengaruhpengaruh. Hasil penelitian menunjukkan bahwa faktor pemanfaatan yang direncanakan digunakan dalam masalah perencanaan agregat dimana memiliki pengaruh yang tinggi pada biaya yang optimal (Klaus Attendofer, 2016). 
Tujuan dari penelitian ini adalah untuk melakukan perencanaan jangka panjang berupa perencanaan kapasitas dan perencanaan menengah sesuai dengan kerangka perencanaan dan pengendalian produksi.

\section{Tinjauan Pustaka}

\subsection{Perencanaan dan Pengendalian Produksi}

The American Production and Inventory

Society mendefinisikan perencanaan produksi sebagai berikut:

a. Perencanaan produksi ialah suatu kegiatan yang berkenaan dengan penentuan apa yang harus diproduksi, berapa banyak diproduksi dan apa sumber daya yang dibutuhkan untuk mendapatkan produk yang telah ditetapkan.

b. Pengendalian produksi ialah fungsi yang mengarahkan atau mengatur pergerakan material (bahan, part/ komponen/ subassembly dan produk) melalui seluruh siklus manufacturing mulai dari permintaan bahan baku sampai pada pengiriman produk akhir pada pelanggan.

Ada tiga sasaran pokok yang sekaligus menjadi barometer keberhasilan perencanaan dan pengendalian produksi yaitu:

a. Tercapainya kepuasan pelanggan yang diukur dari terpenuhinya order terhadap produk tepat waktu, tepat jumlah dan tepat mutu.

b. Tercapainya tingkat utilitas sumber daya produksi yang maksimum melalui minimisasi waktu setup, transportasi, waktu menunggu dan waktu untuk pengerjaan ulang (rework).

c. Terhindarnya cara pengadaan yang bersifat rush order dan persediaan yang berlebihan.

\subsection{Kerangka Dasar Sistem Perencanaan dan Pengendalian Produksi}

Sistem perencanaan dan pengendalian produksi terdiri dari beberapa sub-sistem yang dirancang untuk mencapai secara utuh dua sasaran pokok perencanaan dan pengendalian produksi yaitu tercapainya kepuasan pelanggan dan tingginya tingkat utilisasi penggunaan sumber daya produksi. Agar sasaran tersebut dapat dicapai secara maksimum maka seluruh sub-sistem harus secara sinergik melakukan fungsi-fungsi perencanaan dan pengendalian misalnya perencanaan dan pengendalian bahan, kapasitas dan proses produksi.

Kerangka dasar sistem perencanaan dan pengendalian produksi yang terintegrasi dan aliran informasi antar sub-sistem adalah seperti terlihat pada Gambar 2.1.

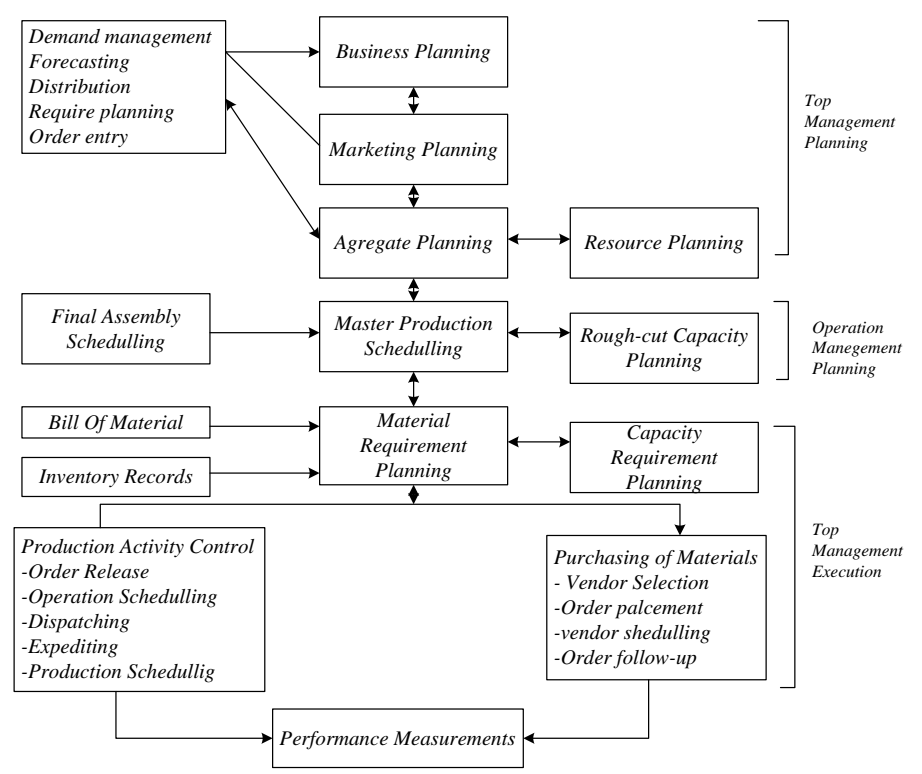

Gambar 2.1. Kerangka Dasar Perencanaan dan Pengendalian Produksi

\subsection{Perencanaan Agregat}

Perencanaan agregat merupakan salah satu metode dalam perancanaan produksi. Dengan menggunakan perencanaan agregat maka perencanaan produksi dapat dilakukan dengan menggunakan satuan produk pengganti sehingga keluaran dari perencanaan produksi tidak dinyatakan dalam tiap jenis produk (individual produk).

Jadi dalam perencanaan agregat, tidak dihasilkan rencana dalam bentuk individual produk melainkan dalam bentuk agregat produk.

\subsubsection{Strategi Perencanaan Agregat}

Ada beberapa strategi yang dapat dilakukan untuk melakukan perencanaan yaitu dengan melakukan manipulasi persediaan, laju produksi, jumlah tenaga kerja, kapasitas atau variabel terkendali lainnya. Jika perubahan dilakukan terhadap suatu variabel sehingga terjadi perubahan laju produksi disebut sebagai strategi murni (pure strategy). Sebaliknya, strategi gabungan (mixed strategy), merupakan gabungan perubahan dua atau lebih strategi murni sehingga diperoleh perencanaan produksi fleksibel.

1. Strategi Perencanaan Agregat Secara Murni (Pure Strategy)

Dikatakan pure strategy, jika perubahan dilakukan terhadap suatu variabel sehingga terjadi perubahan laju produksi. Beberapa strategi murni yaitu:

a. Mengendalikan jumlah persediaan

Persediaan dapat dilakukan pada saat kapasitas produksi di bawah permintaan (demand). Persediaan ini selanjutnya dapat digunakan pada saat permintaan berada di atas kapasitas produksi.

b. Mengendalikan jumlah tenaga kerja

Manajer dapat melakukan perubahan jumalah tenaga kerja dengan menambah atau mengurangi tenaga kerja sesuai dengan laju 
produksi yang diinginkan. Tindakan lainnya yang dapat dilakukan yaitu dengan menambah jam kerja atau lembur.

c. Subkontrak

Subkontak dapat dilakukan untuk menaikan kapasitas perusahaan pada saat perusahaan sibuk sehingga permintaan dapat dipenuhi.

d. Mempengaruhi demand

Karena perubahan permintaan merupakan factor utama dalam masalah perencanaan agregat, maka pihak manajemen dapat melakukan tindakan, yaitu dengan mempengaruhi pola permintaan itu sendiri.

\section{Strategi Perencanaan Agregat Secara}

Gabungan (Mixed Strategy)

Setiap pure strategy akan melibatkan biaya yang besar dan sering pure strategy menjadi tidak layak. Oleh karena itu, kombinasi dari pure strategy ini menjadi mixed strategy ini lebih sering digunakan. Ketika suatu perusahaan mempertimbangkan kemungkinan dari pencampuran strategi yang bervariasi dengan tidak terbatasnya rasio untuk melakukan strategi yang bervariasi tersebut, maka perusahaan baru akan menyadari tantangan yang sedang dihadapinya. Bagian pengendalian produksi dan bagian pemasaran harus menghasilkan master schedule yang mencakup beberapa kebijaksanaan perubahan dan prosedur pengoperasian.

\subsubsection{Metode Perencanaan Agregat}

Banyak metode yang telah dikembangkan untuk perencanaan agregat ini tetapi pada dasarnya dapat dikelompokkan menjadi dua kelompok yaitu:

1. Dengan pendekatan optimasi:
a. Program Linier
b. Linier Decision Rule
c. Search Decision Rule

2. Dengan pendekatan heuristik:
a. Metode Grafik
b. Metode Koefisien Manajemen
c. Metode Parametric

Tidak semua metode ini akan dijelaskan, namun pada prisipnya semua metode yang akan menghasilkan kecepatan produksi pada periode perencanaan yang dibuat, jumlah tenaga kerja yang digunakan, serta tingkat persediaan yang terjadi.

\section{Metodologi dan Pengumpulan Data \\ 3.1. Metodologi Penelitian}

Penelitian ini bersifat penelitian studi kasus (Case Study). Langkah langkah penelitian yaitu dimulai dari melakukan peramalan data-data permintaan dan dilanjutkan dengan melekukan perencanaan agregat. Setelah melakukan perencanaan agregat makan dapat dibuat jadwal induk produksi untuk permintaan produk. Setelah terbentuk jadwal induk produksi, maka langkah selanjutnya adalah melakukan perencanaan kapasitas kebutuhan kasar (Rough Cut Capacity Planning). Setelah itu, disusun material requirement planning (MRP) untuk dapat membentuk perencanaan kapasitas (Capacity Requirement Planning). Tahap akhir adalah dengan melakukan production activity control untuk pengendalian kapasitas.

\subsection{Pengumpulan Data}

Pengumpulan data dilakukan secara tidak langsung yaitu memperoleh data dari Badab Pusat Statistik sehingga diperoleh data sekunder untuk melakukan penelitian ini. Dan untuk data waktu dilakukan secara langsung pada proses perakitan, sehingga diperoleh data primer pengamatan secara langsung. Tabel 3.1.

Data peramalan produk dapat dilihat pada

Tabel 3.1. Hasil Peramalan 2018

\begin{tabular}{|c|c|c|}
\hline Bulan & Indeks & Peramalan \\
\hline Januari & 0,0870 & 158.006 \\
\hline Februari & 0,0920 & 167.087 \\
\hline Maret & 0,0800 & 145.293 \\
\hline April & 0,0680 & 123.499 \\
\hline Mei & 0,0780 & 141.661 \\
\hline Juni & 0,0960 & 174.352 \\
\hline Juli & 0,0790 & 143.477 \\
\hline Agustus & 0,0950 & 172.535 \\
\hline September & 0,0880 & 159.822 \\
\hline Oktober & 0,0750 & 136.212 \\
\hline November & 0,0900 & 163.455 \\
\hline Desember & 0,0720 & 130.764 \\
\hline \multicolumn{2}{|c|}{ Jumlah } & 1.816 .163 \\
\hline
\end{tabular}

Tabel 3.2. Waktu Baku Setiap Work Center

\begin{tabular}{ccc}
\hline $\begin{array}{c}\text { Work } \\
\text { Center }\end{array}$ & $\begin{array}{c}\text { Waktu Kerja } \\
\text { (detik) }\end{array}$ & $\begin{array}{c}\text { Waktu Baku } \\
\text { (jam) }\end{array}$ \\
\hline I & 500 & 0,1389 \\
II & 500 & 0,1389 \\
III & 507 & 0,1409 \\
IV & 507 & 0,1409 \\
V & 507 & 0,1409 \\
\hline
\end{tabular}

Tabel 3.3. Data Perencanaan Agregat

\begin{tabular}{lc}
\hline \multicolumn{1}{c}{ Paramater } & Ket \\
\hline Jam Kerja/Hari & 8 jam \\
Tingkat Absensi & $3 \%$ \\
Biaya Produksi RT (Rp/hari/orang) & 60.000 \\
Biaya Produksi OT (Rp/jam/orang) & 90.000 \\
Biaya Subkontrak (Rp/unit) & 105.000 \\
Persediaan Awal (unit) & $\mathrm{IMR}$ \\
Persediaan Akhir (unit) & $10 \%$ \\
Kapasitas Overtime (jam) & 10 \\
Kapasitas Subkontrak (unit) & 5.000 \\
Biaya Penyimpanan (Rp/unit) & $\mathrm{IMR}$ \\
Jumlah Tenaga Kerja Awal (orang) & 8 \\
Biaya Backorder (Rp/unit) & - \\
Maksimum Periode Backorder & - \\
Biaya Rekrut Tenaga Kerja Baru (Rp/orang) & 560.000 \\
Biaya Pecat Tenaga Kerja (Rp/orang) & 902.000 \\
Biaya Rekrut/pemecatan awal (Rp) & 0 \\
Faktor Inflasi/Deflasi & 1 \\
Lead Time yang Ditetapkan & $1 \mathrm{bulan}$ \\
Penalty Keterlambatan (RP/Tardy) & 45.000 .000 \\
\hline
\end{tabular}


Tabel 3.4. Work Center Master Files

\begin{tabular}{|c|c|c|c|c|c|}
\hline WC & $\mathbf{N}$ & $\begin{array}{c}\text { Jumlah } \\
\text { Hari Kerja }\end{array}$ & $\begin{array}{c}\text { Jam } \\
\text { Kerja }\end{array}$ & $\begin{array}{c}\text { Jam kerja } \\
\text { /bulan }\end{array}$ & $\begin{array}{c}\text { Waktu } \\
\text { Tersedia }\end{array}$ \\
\hline \multirow{12}{*}{ I } & 1 & 26 & 8 & 208 & 416 \\
\hline & 2 & 24 & 8 & 192 & 384 \\
\hline & 3 & 26 & 8 & 208 & 416 \\
\hline & 4 & 26 & 8 & 208 & 416 \\
\hline & 5 & 25 & 8 & 200 & 400 \\
\hline & 6 & 26 & 8 & 208 & 416 \\
\hline & 7 & 26 & 8 & 208 & 416 \\
\hline & 8 & 26 & 8 & 208 & 416 \\
\hline & 9 & 27 & 8 & 216 & 432 \\
\hline & 10 & 26 & 8 & 208 & 416 \\
\hline & 11 & 27 & 8 & 216 & 432 \\
\hline & 12 & 27 & 8 & 216 & 432 \\
\hline \multirow{12}{*}{ II } & 1 & 26 & 8 & 208 & 416 \\
\hline & 2 & 24 & 8 & 192 & 384 \\
\hline & 3 & 26 & 8 & 208 & 416 \\
\hline & 4 & 26 & 8 & 208 & 416 \\
\hline & 5 & 25 & 8 & 200 & 400 \\
\hline & 6 & 26 & 8 & 208 & 416 \\
\hline & 7 & 26 & 8 & 208 & 416 \\
\hline & 8 & 26 & 8 & 208 & 416 \\
\hline & 9 & 27 & 8 & 216 & 432 \\
\hline & 10 & 26 & 8 & 208 & 416 \\
\hline & 11 & 27 & 8 & 216 & 432 \\
\hline & 12 & 27 & 8 & 216 & 432 \\
\hline \multirow{12}{*}{ III } & 1 & 26 & 8 & 208 & 416 \\
\hline & 2 & 24 & 8 & 192 & 384 \\
\hline & 3 & 26 & 8 & 208 & 416 \\
\hline & 4 & 26 & 8 & 208 & 416 \\
\hline & 5 & 25 & 8 & 200 & 400 \\
\hline & 6 & 26 & 8 & 208 & 416 \\
\hline & 7 & 26 & 8 & 208 & 416 \\
\hline & 8 & 26 & 8 & 208 & 416 \\
\hline & 9 & 27 & 8 & 216 & 432 \\
\hline & 10 & 26 & 8 & 208 & 416 \\
\hline & 11 & 27 & 8 & 216 & 432 \\
\hline & 12 & 27 & 8 & 216 & 432 \\
\hline \multirow{12}{*}{ IV } & 1 & 26 & 8 & 208 & 416 \\
\hline & 2 & 24 & 8 & 192 & 384 \\
\hline & 3 & 26 & 8 & 208 & 416 \\
\hline & 4 & 26 & 8 & 208 & 416 \\
\hline & 5 & 25 & 8 & 200 & 400 \\
\hline & 6 & 26 & 8 & 208 & 416 \\
\hline & 7 & 26 & 8 & 208 & 416 \\
\hline & 8 & 26 & 8 & 208 & 416 \\
\hline & 9 & 27 & 8 & 216 & 432 \\
\hline & 10 & 26 & 8 & 208 & 416 \\
\hline & 11 & 27 & 8 & 216 & 432 \\
\hline & 12 & 27 & 8 & 216 & 432 \\
\hline \multirow{12}{*}{ V } & 1 & 26 & 8 & 208 & 416 \\
\hline & 2 & 24 & 8 & 192 & 384 \\
\hline & 3 & 26 & 8 & 208 & 416 \\
\hline & 4 & 26 & 8 & 208 & 416 \\
\hline & 5 & 25 & 8 & 200 & 400 \\
\hline & 6 & 26 & 8 & 208 & 416 \\
\hline & 7 & 26 & 8 & 208 & 416 \\
\hline & 8 & 26 & 8 & 208 & 416 \\
\hline & 9 & 27 & 8 & 216 & 432 \\
\hline & 10 & 26 & 8 & 208 & 416 \\
\hline & 11 & 27 & 8 & 216 & 432 \\
\hline & 12 & 27 & 8 & 216 & 432 \\
\hline
\end{tabular}

4. Pembahasan

\subsection{Perencaan Jangka Panjang}

\subsubsection{Peramalan}

Penjualan produk Radio Souness SNI 4250 pada tahun 2018 ditargetkan sebesar 1,00\%, hal ini diasumsikan karena kondisi pasar, banyaknya perusahaan sejenis dengan produk yang sejenis. Data hasil peramalan untuk jumlah penjualan produk Radio Souness SNI 4250 selama tahun 2018 yang dinyatakan per bulan dapat dilihat pada Tabel 4.1 .

\subsubsection{Perencanaan Agregat}

Penentuan jumlah dan biaya tenaga kerja yang diperlukan untuk mengerjakan produk Radio Souness SNI 4250 dibutuhkan data hari kerja yang dapat ditunjukkan sebagai berikut.

Tabel 4.1. Peramalan Produk Tahun 2018

\begin{tabular}{|c|c|c|c|}
\hline Bulan & Indeks & Forecast & $\begin{array}{l}\text { Target } \\
\text { Pasar }\end{array}$ \\
\hline Januari & 0,0870 & 158.006 & 1.581 \\
\hline Februari & 0,0920 & 167.087 & 1.671 \\
\hline Maret & 0,0800 & 145.293 & 1.453 \\
\hline April & 0,0680 & 123.499 & 1.235 \\
\hline Mei & 0,0780 & 141.661 & 1.417 \\
\hline Juni & 0,0960 & 174.352 & 1.744 \\
\hline Juli & 0,0790 & 143.477 & 1.435 \\
\hline Agustus & 0,0950 & 172.535 & 1.726 \\
\hline September & 0,0880 & 159.822 & 1.599 \\
\hline Oktober & 0,0750 & 136.212 & 1.363 \\
\hline November & 0,0900 & 163.455 & 1.635 \\
\hline Desember & 0,0720 & 130.764 & 1.308 \\
\hline \multicolumn{2}{|c|}{ Jumlah } & 1.816 .163 & 18.167 \\
\hline
\end{tabular}

Tabel 4.2. Rekapitulasi Waktu Baku Jumlah Tenaga Kerja Sekarang

\begin{tabular}{|c|c|c|c|c|}
\hline \multirow[t]{2}{*}{$W / C$} & \multirow{2}{*}{$\begin{array}{c}\text { Waktu } \\
\text { Baku } \\
\text { (detik) }\end{array}$} & \multirow{2}{*}{$\begin{array}{c}\text { Waktu } \\
\text { Baku } \\
\text { (jam) }\end{array}$} & \multicolumn{2}{|c|}{$\begin{array}{c}\text { Tenaga Kerja } \\
\text { Sekarang }\end{array}$} \\
\hline & & & Jumlah & Waktu baku \\
\hline I & 500 & 0,1389 & 1 & $\mathbf{0 , 1 3 8 8 9}$ \\
\hline II & 500 & 0,1389 & 1 & 0,13889 \\
\hline III & 507 & 0,1408 & 2 & 0,07042 \\
\hline IV & 507 & 0,1408 & 2 & 0,07042 \\
\hline $\mathrm{V}$ & 507 & 0,1408 & 2 & 0,07042 \\
\hline
\end{tabular}

Tabel 4.3. Rekapitulasi Waktu Baku Jumlah Tenaga Kerja Usulan

\begin{tabular}{ccccc}
\hline \multirow{2}{*}{ W/C } & \multirow{2}{*}{$\begin{array}{c}\text { Waktu } \\
\text { Baku }\end{array}$} & $\begin{array}{c}\text { Waktu } \\
\text { Baku }\end{array}$ & \multicolumn{2}{c}{$\begin{array}{c}\text { Tenaga Kerja } \\
\text { Sekarang }\end{array}$} \\
\cline { 4 - 5 } & (detik) & (jam) & $\begin{array}{c}\text { Jumlah } \\
\text { (orang) }\end{array}$ & $\begin{array}{c}\text { Waktu } \\
\text { Baku/ orang }\end{array}$ \\
\hline I & 500 & 0,1389 & 2 & 0,06944 \\
II & 500 & 0,1389 & 2 & 0,06944 \\
III & $\mathbf{5 0 7}$ & $\mathbf{0 , 1 4 0 8}$ & $\mathbf{2}$ & $\mathbf{0 , 0 7 0 4 2}$ \\
IV & 507 & 0,1408 & 2 & 0,07042 \\
V & 507 & 0,1408 & 2 & 0,07042 \\
\hline
\end{tabular}


Tabel 4.4. Rekapitulasi Biaya RT. Biaya OT. dan Biaya Subkontrak

\begin{tabular}{|c|c|c|c|c|}
\hline \multirow{2}{*}{$\begin{array}{c}\text { Jumlah } \\
\text { Tenaga } \\
\text { Kerja }\end{array}$} & \multirow[b]{2}{*}{$\begin{array}{c}\text { Waktu } \\
\text { Baku }\end{array}$} & \multicolumn{3}{|c|}{ Biaya / Unit } \\
\hline & & $\begin{array}{c}\text { Regular } \\
\text { Time }\end{array}$ & $\begin{array}{c}\text { Overti } \\
\text { me }\end{array}$ & $\begin{array}{c}\text { Sub } \\
\text { Kontrak }\end{array}$ \\
\hline Sekarang & 0,13889 & 8.333 & 60.000 & 105.000 \\
\hline Usulan & 0,07042 & 5.282 & 38.027 & 105.000 \\
\hline
\end{tabular}

\subsubsection{Penentuan Kapasitas Produksi Per Periode}

Untuk menentukan kapasitas produksi. dilakukan penjumlahan kapasitas regular time overtime dan subkontrak untuk setiap bulan selama tahun 2018. Jam kerja lembur (terdapat pada pengumpulan data) sebesar 10 jam. Jumlah tenaga kerja awal juga telah diketahui sebelumnya yaitu sebanyak 8 orang. Rumus perhitungannya yaitu: Reguler Time Capacity $=\frac{\text { Jlh Hari Kerja } \times \text { Jlh Jam Kerja Efektif }}{\text { Waktu Standar }}$

Overtime Capacity $=\frac{\text { Jlh Hari Kerja } \times \text { Jlh Jam Lembur }}{\text { Waktu Standar }}$

Tabel 4.5. Penentuan Kapasitas Produksi dengan Jumlah Tenaga Kerja Sekarang

\begin{tabular}{|c|c|c|c|c|c|c|c|}
\hline \multirow[b]{2}{*}{$\mathbf{N}$} & \multirow{2}{*}{$\begin{array}{l}\text { Jam } \\
\text { kerja } \\
\text { efektif }\end{array}$} & \multirow{2}{*}{$\begin{array}{c}\text { Jlh } \\
\text { jam } \\
\text { OT }\end{array}$} & \multirow{2}{*}{$\begin{array}{c}\text { Waktu } \\
\text { Baku } \\
\text { (jam } \\
\text { /unit) }\end{array}$} & \multirow[b]{2}{*}{$\begin{array}{l}\text { Jlh } \\
\text { TK }\end{array}$} & \multicolumn{3}{|c|}{ Kapasitas (Unit) } \\
\hline & & & & & RT & OT & $\begin{array}{c}\text { SK } \\
\text { (unit) }\end{array}$ \\
\hline 1 & 7,76 & 10 & 0,138 & 8 & 1.452 & 311 & 5.000 \\
\hline 2 & 7,76 & 10 & 0,138 & 8 & 1.340 & 287 & 5.000 \\
\hline 3 & 7,76 & 10 & 0,138 & 8 & 1.452 & 311 & 5.000 \\
\hline 4 & 7,76 & 10 & 0,138 & 8 & 1.452 & 311 & 5.000 \\
\hline 5 & 7,76 & 10 & 0,138 & 8 & 1.396 & 299 & 5.000 \\
\hline 6 & 7,76 & 10 & 0,138 & 8 & 1.452 & 311 & 5.000 \\
\hline 7 & 7,76 & 10 & 0,138 & 8 & 1.452 & 311 & 5.000 \\
\hline 8 & 7,76 & 10 & 0,138 & 8 & 1.452 & 311 & 5.000 \\
\hline 9 & 7,76 & 10 & 0,138 & 8 & 1.508 & 323 & 5.000 \\
\hline 10 & 7,76 & 10 & 0,138 & 8 & 1.452 & 311 & 5.000 \\
\hline 11 & 7,76 & 10 & 0,138 & 8 & 1.508 & 323 & 5.000 \\
\hline 12 & 7,76 & 10 & 0,138 & 8 & 1.508 & 323 & 5.000 \\
\hline
\end{tabular}

Tabel 4.6. Penentuan Kapasitas Produksi

dengan Jumlah Tenaga Kerja Usulan

\begin{tabular}{|c|c|c|c|c|c|c|c|}
\hline \multirow[b]{2}{*}{$\mathbf{N}$} & \multirow{2}{*}{$\begin{array}{l}\text { Jam } \\
\text { kerja } \\
\text { efektif }\end{array}$} & \multirow[b]{2}{*}{$\begin{array}{c}\text { Jlh } \\
\text { jam } \\
\text { OT }\end{array}$} & \multirow{2}{*}{$\begin{array}{c}\text { Waktu } \\
\text { Baku } \\
\text { (jam } \\
\text { /unit) } \\
\end{array}$} & \multirow[b]{2}{*}{$\begin{array}{l}\text { Jlh } \\
\text { TK }\end{array}$} & \multicolumn{3}{|c|}{ Kapasitas (Unit) } \\
\hline & & & & & RT & OT & SK \\
\hline 1 & 7,76 & 10 & 0,070 & 2 & 2.865 & 615 & 5.000 \\
\hline 2 & 7,76 & 10 & 0,070 & 2 & 2.644 & 568 & 5.000 \\
\hline 3 & 7,76 & 10 & 0,070 & 2 & 2.865 & 615 & 5.000 \\
\hline 4 & 7,76 & 10 & 0,070 & 2 & 2.865 & 615 & 5.000 \\
\hline 5 & 7,76 & 10 & 0,070 & 2 & 2.754 & 591 & 5.000 \\
\hline 6 & 7,76 & 10 & 0,070 & 2 & 2.865 & 615 & 5.000 \\
\hline 7 & 7,76 & 10 & 0,070 & 2 & 2.865 & 615 & 5.000 \\
\hline 8 & 7,76 & 10 & 0,070 & 2 & 2.865 & 615 & 5.000 \\
\hline 9 & 7,76 & 10 & 0,070 & 2 & 2.975 & 639 & 5.000 \\
\hline 10 & 7,76 & 10 & 0,070 & 2 & 2.865 & 615 & 5.000 \\
\hline 11 & 7,76 & 10 & 0,070 & 2 & 2.975 & 639 & 5.000 \\
\hline 12 & 7,76 & 10 & 0,070 & 2 & 2.975 & 639 & 5.000 \\
\hline
\end{tabular}

4.2. Perencanaan Jangka Menengah

4.2.1. Rough-Cut Capacity Planning (RCCP)

4.2.1.1. Perhitungan Kapasitas yang Dibutuhkan (Capacity Requirement)

Sebelum melakukan perhitungan terhadap

kapasitas yang dibutuhkan untuk setiap work center maka perlu diketahui terlebih dahulu waktu baku setiap work center tersebut pada Tabel 3.2. Perhitungan kapasitas seperti dibawah ini.

$$
\text { Capacity Requirement }=\sum_{k=1}^{n} a_{k} b_{k}
$$

untuk semua $\mathrm{i}$ j

Keterangan:

$a_{i k} \quad=$ waktu baku pengerjaan produk $\mathrm{k}$ pada stasiun kerja i

$b_{i k} \quad=$ jumlah produk $\mathrm{k}$ yang akan dijadwalkan pada periode $\mathrm{j}$

Contoh Perhitungan:

CR Januari di Work Center $\mathrm{I}=0,06944 \times$ $1.431=99,369$ jam

Tabel 4.7. Perhitungan Kapasitas yang Dibutuhkan

\begin{tabular}{|c|c|c|c|c|}
\hline W/C & $\mathbf{N}$ & $\begin{array}{l}\text { Waktu baku } \\
\text { (jam/unit) }\end{array}$ & $\begin{array}{l}\text { Jadwal } \\
\text { Jumlah } \\
\text { Produk } \\
\end{array}$ & $\begin{array}{c}\text { Capacity } \\
\text { Requirement } \\
\text { (Jam) }\end{array}$ \\
\hline \multirow{12}{*}{ I } & 1 & 0,06944 & 1.431 & 99,369 \\
\hline & 2 & 0,06944 & 1.671 & 116,034 \\
\hline & 3 & 0,06944 & 1.453 & 100,896 \\
\hline & 4 & 0,06944 & 1.235 & 85,758 \\
\hline & 5 & 0,06944 & 1.417 & 98,397 \\
\hline & 6 & 0,06944 & 1.744 & 121,103 \\
\hline & 7 & 0,06944 & 1.435 & 99,646 \\
\hline & 8 & 0,06944 & 1.726 & 119,854 \\
\hline & 9 & 0,06944 & 1.599 & 111,035 \\
\hline & 10 & 0,06944 & 1.363 & 94,647 \\
\hline & 11 & 0,06944 & 1.635 & 113,534 \\
\hline & 12 & 0,06944 & 1.439 & 99,924 \\
\hline \multirow{12}{*}{ II } & 1 & 0,06944 & 1.431 & 99,369 \\
\hline & 2 & 0,06944 & 1.671 & 116,034 \\
\hline & 3 & 0,06944 & 1.453 & 100,896 \\
\hline & 4 & 0,06944 & 1.235 & 85,758 \\
\hline & 5 & 0,06944 & 1.417 & 98,396 \\
\hline & 6 & 0,06944 & 1.744 & 121,103 \\
\hline & 7 & 0,06944 & 1.435 & 99,646 \\
\hline & 8 & 0,06944 & 1.726 & 119,853 \\
\hline & 9 & 0,06944 & 1.599 & 111,035 \\
\hline & 10 & 0,06944 & 1.363 & 94,647 \\
\hline & 11 & 0,06944 & 1.635 & 113,534 \\
\hline & 12 & 0,06944 & 1.439 & 99,924 \\
\hline \multirow{12}{*}{ III } & 1 & 0,07042 & 1.431 & 100,771 \\
\hline & 2 & 0,07042 & 1.671 & 117,672 \\
\hline & 3 & 0,07042 & 1.453 & 102,320 \\
\hline & 4 & 0,07042 & 1.235 & 86,969 \\
\hline & 5 & 0,07042 & 1.417 & 99,785 \\
\hline & 6 & 0,07042 & 1.744 & 122,812 \\
\hline & 7 & 0,07042 & 1.435 & 101,053 \\
\hline & 8 & 0,07042 & 1.726 & 121,545 \\
\hline & 9 & 0,07042 & 1.599 & 112,602 \\
\hline & 10 & 0,07042 & 1.363 & 95,982 \\
\hline & 11 & 0,07042 & 1.635 & 115,137 \\
\hline & 12 & 0,07042 & 1.439 & 101,334 \\
\hline
\end{tabular}


Tabel 4.7. Perhitungan Kapasitas yang Dibutuhkan (Lanjutan)

\begin{tabular}{ccccc}
\hline W/C & N & $\begin{array}{c}\text { Waktu } \\
\text { Baku } \\
\text { (Jam/ } \\
\text { Unit) }\end{array}$ & $\begin{array}{c}\text { Jadwal } \\
\text { Jumlah } \\
\text { Produk }\end{array}$ & $\begin{array}{c}\text { Capacity } \\
\text { Requirement } \\
\text { (Jam) }\end{array}$ \\
\hline & 1 & 0,07042 & 1.431 & 100,771 \\
& 2 & 0,07042 & 1.671 & 117,672 \\
& 3 & 0,07042 & 1.453 & 102,320 \\
& 4 & 0,07042 & 1.235 & 86,969 \\
& 5 & 0,07042 & 1.417 & 99,785 \\
IV & 6 & 0,07042 & 1.744 & 122,812 \\
& 7 & 0,07042 & 1.435 & 101,053 \\
& 8 & 0,07042 & 1.726 & 121,545 \\
& 9 & 0,07042 & 1.599 & 112,602 \\
& 10 & 0,07042 & 1.363 & 95,982 \\
& 11 & 0,07042 & 1.635 & 115,137 \\
& 12 & 0,07042 & 1.439 & 101,334 \\
\hline & 1 & 0,07042 & 1.431 & 100,771 \\
& 2 & 0,07042 & 1.671 & 117,672 \\
& 3 & 0,07042 & 1.453 & 102,320 \\
& 4 & 0,07042 & 1.235 & 86,969 \\
& 5 & 0,07042 & 1.417 & 99,785 \\
V & 6 & 0,07042 & 1.744 & 122,812 \\
& 7 & 0,07042 & 1.435 & 101,053 \\
& 8 & 0,07042 & 1.726 & 121,545 \\
& 9 & 0,07042 & 1.599 & 112,602 \\
& 10 & 0,07042 & 1.363 & 95,982 \\
& 11 & 0,07042 & 1.635 & 115,137 \\
12 & 0,07042 & 1.439 & 101,334 \\
\hline
\end{tabular}

\subsubsection{Perhitungan Kapasitas yang Tersedia} (Capacity Available)

Perhitungan untuk kapasitas yang tersedia adalah sebagai berikut.

Capacity Available
$=$ WaktuKerjaTersedia $\times \mathrm{Eff} \times \mathrm{Ut}$

Eff $=$ efisiensi

$\mathrm{Ut}=$ utilitas

Utilitas pada seluruh work center

diasumsikan $=100 \%$ karena work center diperkirakan dapat berfungsi secara maksimum yaitu sebesar $100 \%$. Efisiensi pada seluruh work center diasumsikan $=100 \%$ karena efisiensi work center diperkirakan dapat bekerja dengan maksimal dimana waktu standar sama dengan waktu baku. Perhitungan Kapasitas Tersedia (CA) pada setiap work centre dalam setiap bulan dapat dilihat pada contoh perhitungan berikut:

26 hari $\times 8$ jam/hari $\times 2$ pekerja/work centre $=416$ jam

$416 \times 1$ shift $\times 100 \% \times 100 \%=416$

Rekapitulasi dapat dilihat pada tabel sebagai berikut.
Tabel 4.8. Perhitungan Kapasitas yang Tersedia

\begin{tabular}{|c|c|c|c|c|c|}
\hline W/C & $\begin{array}{l}\text { Periode } \\
\text { (Bulan) }\end{array}$ & $\begin{array}{c}\text { Waktu } \\
\text { Kerja } \\
\text { Tersedia }\end{array}$ & Eff & $\mathbf{U t}$ & $\begin{array}{c}\text { Capacity } \\
\text { Available } \\
\text { (Jam) }\end{array}$ \\
\hline \multirow{12}{*}{ I } & Januari & 208 & 1 & 1 & 416 \\
\hline & Februari & 192 & 1 & 1 & 384 \\
\hline & Maret & 208 & 1 & 1 & 416 \\
\hline & April & 208 & 1 & 1 & 416 \\
\hline & Mei & 200 & 1 & 1 & 400 \\
\hline & Juni & 208 & 1 & 1 & 416 \\
\hline & Juli & 208 & 1 & 1 & 416 \\
\hline & Agustus & 208 & 1 & 1 & 416 \\
\hline & September & 216 & 1 & 1 & 432 \\
\hline & Oktober & 208 & 1 & 1 & 416 \\
\hline & November & 216 & 1 & 1 & 432 \\
\hline & Desember & 216 & 1 & 1 & 432 \\
\hline \multirow{12}{*}{ II } & Januari & 208 & 1 & 1 & 416 \\
\hline & Februari & 192 & 1 & 1 & 384 \\
\hline & Maret & 208 & 1 & 1 & 416 \\
\hline & April & 208 & 1 & 1 & 416 \\
\hline & Mei & 200 & 1 & 1 & 400 \\
\hline & Juni & 208 & 1 & 1 & 416 \\
\hline & Juli & 208 & 1 & 1 & 416 \\
\hline & Agustus & 208 & 1 & 1 & 416 \\
\hline & September & 216 & 1 & 1 & 432 \\
\hline & Oktober & 208 & 1 & 1 & 416 \\
\hline & November & 216 & 1 & 1 & 432 \\
\hline & Desember & 216 & 1 & 1 & 432 \\
\hline \multirow{12}{*}{ III } & Januari & 208 & 1 & 1 & 416 \\
\hline & Februari & 192 & 1 & 1 & 384 \\
\hline & Maret & 208 & 1 & 1 & 416 \\
\hline & April & 208 & 1 & 1 & 416 \\
\hline & Mei & 200 & 1 & 1 & 400 \\
\hline & Juni & 208 & 1 & 1 & 416 \\
\hline & Juli & 208 & 1 & 1 & 416 \\
\hline & Agustus & 208 & 1 & 1 & 416 \\
\hline & September & 216 & 1 & 1 & 432 \\
\hline & Oktober & 208 & 1 & 1 & 416 \\
\hline & November & 216 & 1 & 1 & 432 \\
\hline & Desember & 216 & 1 & 1 & 432 \\
\hline \multirow{12}{*}{ IV } & Januari & 208 & 1 & 1 & 416 \\
\hline & Februari & 192 & 1 & 1 & 384 \\
\hline & Maret & 208 & 1 & 1 & 416 \\
\hline & April & 208 & 1 & 1 & 416 \\
\hline & Mei & 200 & 1 & 1 & 400 \\
\hline & Juni & 208 & 1 & 1 & 416 \\
\hline & Juli & 208 & 1 & 1 & 416 \\
\hline & Agustus & 208 & 1 & 1 & 416 \\
\hline & September & 216 & 1 & 1 & 432 \\
\hline & Oktober & 208 & 1 & 1 & 416 \\
\hline & November & 216 & 1 & 1 & 432 \\
\hline & Desember & 216 & 1 & 1 & 432 \\
\hline \multirow{9}{*}{$\mathrm{V}$} & Januari & 208 & 1 & 1 & 416 \\
\hline & Februari & 192 & 1 & 1 & 384 \\
\hline & Maret & 208 & 1 & 1 & 416 \\
\hline & April & 208 & 1 & 1 & 416 \\
\hline & Mei & 200 & 1 & 1 & 400 \\
\hline & Juni & 208 & 1 & 1 & 416 \\
\hline & Juli & 208 & 1 & 1 & 416 \\
\hline & Agustus & 208 & 1 & 1 & 416 \\
\hline & September & 216 & 1 & 1 & 432 \\
\hline
\end{tabular}


Tabel 4.8. Perhitungan Kapasitas yang Tersedia (Lanjutan)

\begin{tabular}{|c|c|c|c|c|c|}
\hline W/C & $\begin{array}{l}\text { Periode } \\
\text { (Bulan) }\end{array}$ & $\begin{array}{c}\text { Waktu } \\
\text { Kerja } \\
\text { Tersedia }\end{array}$ & Eff & $\mathbf{U t}$ & $\begin{array}{r}\text { Capaci } \\
\text { Availab } \\
\text { (Jam) }\end{array}$ \\
\hline \multirow{3}{*}{$\mathrm{V}$} & Oktober & 208 & 1 & 1 & 416 \\
\hline & November & 216 & 1 & 1 & 432 \\
\hline & Desember & 216 & 1 & 1 & 432 \\
\hline
\end{tabular}

Identifikasi stasiun kerja dilakukan dengan indikator Drum dan Non Drum. Suatu stasiun kerja dikatakan Drum jika kapasitas yang dimiliki stasiun kerja lebih kecil dari kebutuhan produksi. Sedangkan Non Drum jika kapasitas yang dimiliki stasiun kerja lebih besar dari kebutuhan produksi. Drum akan terjadi berupa antrian jika ada peningkatan permintaan yang melebihi kapasitas.

Contoh Perhitungan:

Work Center I bulan Januari

Kapasitas yang Dibutuhkan $(C R)=99,369$

Kapasitas yang Tersedia $(\mathrm{CA})=416$

Maka Varians $=\mathrm{CR}-\mathrm{CA}$

$=(99,369-416) \mathrm{jam}$

$=-316,631$ jam

Artinya terdapat kapasitas yang berlebih sebesar 206,0191 jam.

Beban $=\frac{\mathrm{CR}}{\mathrm{CA}}=\frac{99,369 \mathrm{jam}}{416 \mathrm{jam}}=0,2389$

Hasil Rough Cut Capacity Planning

(RCCP) dapat dilihat pada Tabel 4.9.

Tabel 4.9. Rough Cut Capacity Planning

\begin{tabular}{ccccccc}
\hline W/C & N & $\begin{array}{c}\text { CR } \\
(\text { Jam })\end{array}$ & $\begin{array}{c}\text { CA } \\
(\text { Jam })\end{array}$ & Varians & CR/ & Ket \\
\hline \multirow{4}{*}{ I } & 1 & 99,369 & 416 & $-316,631$ & 0,23 & Non Drum \\
& 2 & 116,034 & 384 & $-267,966$ & 0,30 & Non Drum \\
& 3 & 100,896 & 416 & $-315,104$ & 0,24 & Non Drum \\
& 4 & 85,758 & 416 & $-330,242$ & 0,20 & Non Drum \\
& 5 & 98,397 & 400 & $-301,604$ & 0,24 & Non Drum \\
& 6 & 121,103 & 416 & $-294,897$ & 0,29 & Non Drum \\
& 7 & 99,646 & 416 & $-316,354$ & 0,23 & Non Drum \\
& 8 & 119,854 & 416 & $-296,147$ & 0,28 & Non Drum \\
& 9 & 111,035 & 432 & $-320,965$ & 0,25 & Non Drum \\
& 10 & 94,647 & 416 & $-321,353$ & 0,22 & Non Drum \\
& 11 & 113,534 & 432 & $-318,466$ & 0,26 & Non Drum \\
& 12 & 99,924 & 432 & $-332,076$ & 0,23 & Non Drum \\
& 1 & 99,369 & 416 & $-316,631$ & 0,23 & Non Drum \\
& 2 & 116,034 & 384 & $-267,966$ & 0,30 & Non Drum \\
& 3 & 100,896 & 416 & $-315,104$ & 0,24 & Non Drum \\
& 4 & 85,758 & 416 & $-330,242$ & 0,20 & Non Drum \\
& 5 & 98,397 & 400 & $-301,604$ & 0,24 & Non Drum \\
& 6 & 121,103 & 416 & $-294,897$ & 0,29 & Non Drum \\
& 7 & 99,646 & 416 & $-316,354$ & 0,23 & Non Drum \\
& 8 & 119,854 & 416 & $-296,147$ & 0,28 & Non Drum \\
9 & 111,035 & 432 & $-320,965$ & 0,25 & Non Drum \\
& 10 & 94,647 & 416 & $-321,353$ & 0,22 & Non Drum \\
& 11 & 113,534 & 432 & $-318,466$ & 0,26 & Non Drum \\
& 12 & 99,924 & 432 & $-332,076$ & 0,23 & Non Drum \\
\hline \multirow{4}{*}{} & & & & & & \\
& & & & &
\end{tabular}

Tabel 4.9. Rough Cut Capacity Planning (Lanjutan)

\begin{tabular}{|c|c|c|c|c|c|c|}
\hline W/C & $\mathbf{N}$ & $\begin{array}{c}\text { CR } \\
(\text { Jam) }\end{array}$ & $\begin{array}{c}\text { CA } \\
(\text { Jam) }\end{array}$ & Varians & $\begin{array}{l}\mathrm{CR} / \\
\mathrm{CA}\end{array}$ & Ket \\
\hline \multirow{12}{*}{ III } & 1 & 100,771 & 416 & $-315,229$ & 0,24 & Non Drum \\
\hline & 2 & 117,672 & 384 & $-266,328$ & 0,30 & Non Drum \\
\hline & 3 & 102,320 & 416 & $-313,680$ & 0,24 & Non Drum \\
\hline & 4 & 86,969 & 416 & $-329,031$ & 0,20 & Non Drum \\
\hline & 5 & 99,785 & 400 & $-300,215$ & 0,24 & Non Drum \\
\hline & 6 & 122,812 & 416 & $-293,188$ & 0,29 & Non Drum \\
\hline & 7 & 101,053 & 416 & $-314,947$ & 0,24 & Non Drum \\
\hline & 8 & 121,545 & 416 & $-294,455$ & 0,29 & Non Drum \\
\hline & 9 & 112,602 & 432 & $-319,399$ & 0,26 & Non Drum \\
\hline & 10 & 95,982 & 416 & $-320,018$ & 0,23 & Non Drum \\
\hline & 11 & 115,137 & 432 & $-316,863$ & 0,26 & Non Drum \\
\hline & 12 & 101,334 & 432 & $-330,666$ & 0,23 & Non Drum \\
\hline \multirow{12}{*}{ IV } & 1 & 100,771 & 416 & $-315,229$ & 0,24 & Non Drum \\
\hline & 2 & 117,672 & 384 & $-266,328$ & 0,30 & Non Drum \\
\hline & 3 & 102,320 & 416 & $-313,680$ & 0,24 & Non Drum \\
\hline & 4 & 86,969 & 416 & $-329,031$ & 0,20 & Non Drum \\
\hline & 5 & 99,785 & 400 & $-300,215$ & 0,24 & Non Drum \\
\hline & 6 & 122,812 & 416 & $-293,188$ & 0,29 & Non Drum \\
\hline & 7 & 101,053 & 416 & $-314,947$ & 0,24 & Non Drum \\
\hline & 8 & 121,545 & 416 & $-294,455$ & 0,29 & Non Drum \\
\hline & 9 & 112,602 & 432 & $-319,399$ & 0,26 & Non Drum \\
\hline & 10 & 95,982 & 416 & $-320,018$ & 0,23 & Non Drum \\
\hline & 11 & 115,137 & 432 & $-316,863$ & 0,26 & Non Drum \\
\hline & 12 & 101,334 & 432 & $-330,666$ & 0,23 & Non Drum \\
\hline \multirow{12}{*}{ V } & 1 & 100,771 & 416 & $-315,229$ & 0,24 & Non Drum \\
\hline & 2 & 117,672 & 384 & $-266,328$ & 0,30 & Non Drum \\
\hline & 3 & 102,320 & 416 & $-313,680$ & 0,24 & Non Drum \\
\hline & 4 & 86,969 & 416 & $-329,031$ & 0,20 & Non Drum \\
\hline & 5 & 99,785 & 400 & $-300,215$ & 0,24 & Non Drum \\
\hline & 6 & 122,812 & 416 & $-293,188$ & 0,29 & Non Drum \\
\hline & 7 & 101,053 & 416 & $-314,947$ & 0,24 & Non Drum \\
\hline & 8 & 121,545 & 416 & $-294,455$ & 0,29 & Non Drum \\
\hline & 9 & 112,602 & 432 & $-319,399$ & 0,26 & Non Drum \\
\hline & 10 & 95,982 & 416 & $-320,018$ & 0,23 & Non Drum \\
\hline & 11 & 115,137 & 432 & $-316,863$ & 0,26 & Non Drum \\
\hline & 12 & 101,334 & 432 & $-330,666$ & 0,23 & Non Drum \\
\hline
\end{tabular}

5. Kesimpulan dan Saran

Kesimpulan dari penelitian ini adalah sebagai berikut :

1. Perencanaan jangka panjang produk Radio Souness SNI 4250 tahun 2018 menggunakan 2 jenis tenaga kerja yaitu tenaga kerja sekarang dan tenaga kerja usulan, dimana untuk tenaga kerja sekarang dengan jumlah tenaga kerja sebanyak 8 memiliki regular time sebesar Rp Rp 8.333 per unit, biaya over time sekarang Rp 60.000 per unit dan biaya subkontrak sekarang sebesar Rp 105.000 per unit. Untuk menghitung biaya tenaga kerja usulan dengan jumlah tenaga kerja sebanyak 10regular time sebesar Rp 5.282 per unit, biaya over time usulan sebesar Rp 38.027 per unit dan biaya subkontrak sebesar Rp 105.000 per unit.

2. Perencanaan jangka menengah menghasilkan Master Production Scheduling dengan total biaya produksi tenaga kerja usulan yaitu sebesar Rp 97.024.862. Perhitungan Rough Cut Capacity Planning menghasilkan status 
kapasitas dari bulan Januari hingga Desember tahun 2018 dengan total non drum sebanyak 60 buah.

Saran yang dapat diberikan untuk penelitian ini adalah sebaiknya pemahaman dan pengaplikasian metode metode perencanaan harus dipahami secara benar

\section{DAFTAR PUSTAKA}

Sarjono, H,dkk. 2016. Planning Production Capacity Optimization With Rough Capacity Planning. Indonesia : Social Sciences an Humanities

Attendofer, Klaus,dkk. 2016. Effect Of Earcase Errors and Optimal Utilisation in Aggregate Production Planning With Stochastic Costumers Demand. International Journal of Production Reaseacrh

Sinulingga, Sukaria. 2009. Perencanaan dan Pengendalian Produksi. Yogyakarta : Graha Ilmu

Ginting, Rosnani. 2007. Sistem Produksi. Yogyakarta : Graha Ilmu

Gasperz, Vincent. 2005. Production Planning and Inventory Control. Jakarta: Gramedia Pustaka Utama 